УДК 637.521:613.292

DOI https://doi.org/10.32851/tnv-tech.2021.4.5

\title{
ВПЛИВ ХАРЧОВИХ ДОБАВОК РОСЛИННОГО ПОХОДЖЕННЯ НА ФУНКЦІОНАЛЬНО-ТЕХНОЛОГІЧНІ ВЛАСТИВОСТІ ЗАМОРОЖЕНИХ М'ЯСНИХ НАПІВФАБРИКАТІВ
}

\author{
Желєва Т.С. - кандидат технічних наук, \\ доцент кафедри технології м'яса \\ Державного біотехнологічного університету \\ ORCID ID: 0000-0002-5701-6543 \\ Розуменко А.P. - студент магістратури фракультету переробних \\ і харчових виробництв \\ Державного біотехнологічного університету \\ ORCID ID: 0000-0003-3277-1785
}

Ця стаття присвячена вивченню впливу харчових добавок рослинного походження, зокрема чотирьох видів харчових волокон, на функиіонально-технологічні властивості заморожених м'ясних напівфабрикатів у тістовій оболониі. 3 огляду на результати проведених аналітичних досліджень встановлено, що серед харчових добавок рослинного походження, які забезпечують збереження якості та стабілізацію структури м'ясних систем під час виробництва заморожених м'ясних напівфабрикатів та чинять позитивний вплив на організм людини, можна виділити харчові волокна. Експериментальні дослідження з визначення їх впливу на функціонально-технологічні властивості заморожених м'ясних напівфабрикатів у тістовій оболонці дозволили відзначити апельсинові харчові волокна «Citri-Fi».

Отримані дані дослідження підтверджують, щзо апельсинові волокна «Citri-Fi» мають дуже високу здатність утримувати воду. Відзначено більш високі значення таких показників, як масова частка вологи, вологозв'язуюча, вологоутримуюча, жироутримуюча здатності й вихід (на 12...15\% вищий порівняно з контролем). Визначено стабільність структурно-механічних властивостей та показника рН зразків після заморожування. Результати органолептичної очінки встановлюють найкращі характеристики для зразка з апельсиновими волокнами "Citri-Fi», що мав гарний зовнішній вигляд $і$ вигляд на розрізі, рівномірно перемішаний фари, соковиту, ніжну консистенцію, приємний смак, запах, властиві доброякісній сировині, сіро-рожевий колір, оболонку з тіста не розірвану, не відсталу від фариу.

Зважаючи на иее, вважаємо перспективним подальший напрям робіт з розробки нових рецептур заморожених м'ясних напівфабрикатів у тістовій оболонці із використанням харчових апельсинових волокон «Citri-Fi», чуо своєю чергою дасть можливість розщирити асортимент високоякісної і конкурентоспроможної м'ясної продукції із заданими властивостями.

Ключові слова: харчові волокна, заморожені м'ясні напівфабрикати у тістовій оболонці, функціонально-технологічні властивості.

Zhelieva T.S., Rozumenko A.R. Influence of plant food additives on functional and technological properties of frozen meat semi-finished products

This article is devoted to the study of the influence of food additives of plant origin, in particular four types of dietary fiber, on the functional and technological properties of frozen meat semi-finished products in the dough shell. Given the results of analytical studies, it was found that among the dietary supplements of plant origin, which ensure the preservation of quality and stabilization of the structure of meat systems in the production of frozen meat products and have a positive effect on the human body, dietary fiber can be identified. Experimental studies to determine their effect on the functional and technological properties of frozen meat semifinished products in the dough shell allowed to note the orange dietary fiber "Citri-Fi".

The obtained research data confirm that "Citri-Fi" orange fibers have a very high ability to retain water. Higher values of such indicators as mass fraction of moisture, moisture-binding, 
moisture-retaining, fat-retaining abilities and yield $(12 \ldots 15 \%$ higher in comparison with the control) were noted. The stability of structural and mechanical properties and $p H$ of samples after freezing was determined. The results of organoleptic evaluation establish the best characteristics for the sample with orange fibers "Citri-Fi", which had a good appearance and sectional view, evenly mixed minced meat, juicy, delicate texture, pleasant taste, odor, characteristic of good quality raw materials, gray-pink color, the shell of the dough is not torn, not behind the stuffing.

In view of this, we consider promising further work on the development of new recipes for frozen meat semi-finished products in a dough shell using dietary orange fiber "Citri-Fi", which in turn will expand the range of high quality and competitive meat products with specified properties.

Key words: dietary fiber, frozen meat semi-finished products in a dough shell, functional and technological properties.

Постановка проблеми. Виробництво заморожених м'ясних напівфабрикатів займає значну частку у м'ясопереробній промисловості країни [1].

Одним із напрямів бізнесу на ринку замороженої м'ясної продукції є виробництво саме м'ясних напівфабрикатів у тістовій оболонці. Дані динаміки виробництва заморожених напівфабрикатів та рівня їх споживання людиною свідчать про щорічне зростання попиту на таку продукцію на рівні $2 . .3 \%$, незважаючи на те, що Україна значно поступається за рівнем споживання напівфабрикатів країнам Європи. Структура українського ринку істотно відрізняється від світової, що зумовлене національними особливостями культури харчування, - ринок орієнтований на виробництво пельменів і вареників [2].

Під час виробництва заморожених м'ясних напівфабрикатів існує необхідність збереження якості та стабілізації структури м'ясних систем, особливо січених, шляхом застосування добавок, що зменшували б вплив низьких температур процесу заморожування та регулювали би консистенцію виробів [3]. А відношення населення до здорового харчування вимагає, щоб такі добавки чинили позитивний вплив на організм людини. Вирішення цієї проблеми можливе шляхом застосування харчових добавок рослинного походження, які мають широкий спектр функціонально-технологічних властивостей.

Аналіз останніх досліджень і публікацій. Кожний інгредієнт рецептури м'ясних виробів має певні функціональні властивості, які спрямовані на досягнення конкретних технологічних цілей. Тож вміло підібрані інгредієнти рецептури впливатимуть на якість готового виробу. 3 метою отримання заданої консистенції та її стабілізації протягом усього періоду зберігання м'ясних виробів виробники застосовують харчові добавки, грамотне використання яких може регулювати консистенцію виробів, та цілеспрямовано варіювати вміст основних компонентів у рецептурі продукту й замінити звичайну сировину на нову [4-6].

Науково-технічні розробки в харчовій промисловості нині спрямовані на створення комбінованих продуктів тваринного та рослинного походження. Виробництво комбінованих м'ясопродуктів передбачає взаємозбагачення їх складу, підвищення біологічної цінності, покращення органолептичних показників готової продукції, зниження ії собівартості. Ці чинники визначають актуальність розвитку вітчизняного виробництва харчових добавок із сировини рослинного походження, що також зумовлено необхідністю вирішення низки соціально-економічних завдань, таких як покращення якості м'ясних виробів, підвищення ефективності виробництва на основі комплексного використання сировини, виробництво спеціалізованих продуктів для дієтичного, лікувально-профілактичного та лікувального харчування для певних категорій і груп населення, створення нових видів м'ясних продуктів [7; 8].

До харчових добавок рослинного походження, які мають широкий спектр функціонально-технологічних властивостей, належать харчові волокна. Вони 
мають високу біологічну і фізіологічну активність, чинять вплив на структурно-механічні властивості готового виробу, зокрема його консистенцію, а також мають позитивний вплив на організм людини [4; 9].

Численні літературні дані [10-11] свідчать, що харчові волокна володіють високою жирозв'язуючою здатністю, стабілізуючими, структуроутримуючими властивостями, антиоксидантною дією, збільшуючи тим самим термін зберігання та покращуючи свіжість харчових продуктів, стійкі до заморожування-розморожування, покращують поживну цінність завдяки вмісту корисної для здоров'я людини дієтичної клітковини.

У м'ясних продуктах харчові волокна використовуються як стабілізатори фаршевих емульсій та напівфабрикатів заморожених для запобігання відділенню вологи під час зберігання виробів, збільшення виходу та покращення показників якості, збагачення м'ясних продуктів корисними для здоров'я харчовими волокнами [11-13].

Розробці технологій м'ясних напівфабрикатів із харчовими волокнами присвячено багато робіт $[4 ; 9 ; 10 ; 13 ; 14]$, однак різноманіття харчових волокон вітчизняного та зарубіжного виробництва на ринку України потребує системних досліджень для окремих видів волокон. Відомо, що властивості харчових волокон визначаються структурою і співвідношенням їх формуючих компонентів, способом їх взаємної упаковки. Значною мірою особливості харчових волокон зумовлені видом рослини, ії віком, технологією виділення. Тому харчові волокна різних видів рослин відмінні один від одного і в кожному конкретному випадку потрібна оцінка їхніх властивостей [15]. Це дозволило визначити напрям подальших експериментальних досліджень та їх актуальність.

Мета дослідження. Метою роботи стало вивчення впливу харчових добавок рослинного походження, зокрема харчових волокон, на функціонально-технологічні властивості заморожених м'ясних напівфабрикатів у тістовій оболонці.

Предметом дослідження стала сировина та матеріали, що необхідні для виробництва заморожених м'ясних напівфабрикатів у тістовій оболонці, та чотири види харчових волокон, представлених на ринку харчових добавок України: апельсинове волокно «Citri-Fi» (TOB «Джорджія»), морквяна клітковина «Нессе» (TOB «Мельниця приправ»), картопляна клітковина «Роtех» (ТОВ «Альфа-Нова»), пшенична клітковина «ВіаФайбер WF1000» (ТОВ «Віанокс»).

Досліджені зразки готували відповідно до рецептури та технологічної схеми виробництва пельменів «Сибірських» [16], м'ясна система за рецептурою яких виступала контрольним зразком для проведення дослідження. Волокна вносили у кількості 1\% до маси м'яса, враховуючи рекомендації фірм-виробників для такого виду продукції. Сировина та матеріали, які використовувалися під час дослідження, за показниками якості й безпечності відповідали вимогам нормативної документації та сертифікатам відповідності фірм-виробників і дозволені для використання в Україні органом виконавчої влади у сфері охорони здоров'я в харчових продуктах. Підготовку та дослідження зразків здійснювали на кафедрі технології м'яса ДБТУ. Дослідження здійснювали за стандартними методиками 3 використанням відповідного обладнання [17].

Виклад основного матеріалу дослідження. Відомо, що однією з основних технологічних властивостей харчових волокон $є$ їх здатність утримувати воду. Тому першим етапом наших досліджень було дослідження цього показника шляхом визначення втрат виходу харчових волокон (табл. 1). 
Втрати виходу харчових волокон, \%

Таблиця 1

\begin{tabular}{|l|c|}
\hline \multicolumn{1}{|c|}{ Види харчових волокон } & Втрати виходу, \% \\
\hline Апельсинове волокно «Citri-Fi» & 29,0 \\
\hline Морквяна клітковина «Нессе» & 39,1 \\
\hline Картопляна клітковина «Роtех» & 54,9 \\
\hline Пшенична клітковина «ВіаФайбер» & 58,2 \\
\hline
\end{tabular}

Результати (табл. 1) свідчать, що найменші втрати характерні для зразка з волокнами «Citri-Fi». Отже, дані дослідження підтверджують, що апельсинові волокна «Citri-Fi» мають дуже високу здатність утримувати воду.

Наступним етапом наших досліджень стала оцінка впливу харчових волокон на функціонально-технологічні властивості заморожених м'ясних напівфабрикатів у тістовій оболонці. Дослідження проводили до і після заморожування. Вихід і органолептичні показники визначали після теплової обробки (варіння).

Отримані дані функціонально-технологічних властивостей заморожених м'ясних напівфабрикатів у тістовій оболонці з харчовими волокнами у їх складі наведені в табл. 2.

Таблиця 2

Функціонально-технологічні властивості заморожених м'ясних напівфабрикатів у тістовій оболонці з харчовими волокнами у їх складі

\begin{tabular}{|l|c|c|c|c|c|}
\hline \multicolumn{1}{|c|}{ Показник } & $\begin{array}{c}\text { Зразок- } \\
\text { контроль }\end{array}$ & $\begin{array}{c}\text { 3разок із } \\
\text { Citri-Fi }\end{array}$ & $\begin{array}{c}\text { 3разок } \\
\text { із Нессе }\end{array}$ & $\begin{array}{c}\text { 3разок } \\
\text { i3 Potex }\end{array}$ & $\begin{array}{c}\text { Зразок і3 } \\
\text { ВіаФай- } \\
\text { бер }\end{array}$ \\
\hline Масова частка вологи, \% & & & & & \\
\hline до заморожування & 74,7 & 73,0 & 71,7 & 72,7 & 73,2 \\
\hline після заморожування & 73,8 & 72,6 & 71,1 & 72,0 & 72,8 \\
\hline Вологозв'язуюча здатність, \% & & & & & \\
\hline до заморожування & 46,8 & 54,5 & 55,4 & 54,1 & 54,3 \\
\hline після заморожування & 44,5 & 52,9 & 54,3 & 53,2 & 53,7 \\
\hline Вологоутримуюча здатність, \% & & & & & \\
\hline до заморожування & 50,1 & 53,8 & 54,6 & 51,7 & 52,9 \\
\hline після заморожування & 49,7 & 53,1 & 51,3 & 51,5 & 51,8 \\
\hline Жироутримуюча здатність, \% & & & & & \\
\hline до заморожування & 25,0 & 24,4 & 25,6 & 25,4 & 27,6 \\
\hline після заморожування & 24,3 & 24,1 & 25,2 & 25,0 & 26,6 \\
\hline рН & & & & & \\
\hline до заморожування & 5,8 & 5,9 & 5,8 & 5,8 & 5,9 \\
\hline після заморожування & 5,8 & 5,9 & 5,8 & 5,8 & 5,9 \\
\hline ГН3 10-2, Па & & & & & \\
\hline до заморожування & 54,5 & 87,2 & 87,0 & 87,2 & 87,3 \\
\hline після заморожування & 54,2 & 87,1 & 87,0 & 87,0 & 87,2 \\
\hline Вихід, \% & & & & & \\
\hline до заморожування & 120,5 & 135,6 & 134,2 & 136,7 & 131,4 \\
\hline після заморожування & 118,2 & 133,8 & 132,1 & 134,7 & 129,3 \\
\hline
\end{tabular}


Аналізуючи результати, можна відзначити, що внесення в м'ясні фарші всіх видів харчових волокон підвищує всі показники ступеня зв'язування води і жиру й відповідно виходу після теплової обробки порівняно з контролем. Відзначено підвищення міцності зразків у разі внесення харчових волокон. Харчові волокна не мали значного впливу на зміну рН м'ясних фаршів.

Загальна картина зміни властивостей дослідних зразків під впливом заморожування свідчить про зниження масової частки вологи, вологозв'язуючої, вологоутримуючої, жироутримуючої здатностей і виходу після заморожування. Однак тенденція більш високих значень таких показників зразків з харчовими волокнами зберігається і після заморожування. Так, вихід залишається вищим на $12 \ldots 15 \%$ порівняно з контролем. Найбільш високі значення цього показника відзначені у зразків із Citri-Fi, Hecce i Potex. Структурно-механічні властивості зразків після заморожування практично не змінюються.

3 огляду на загальний позитивний вплив усіх видів харчових волокон на функціонально-технічні властивості зразків після заморожування, особлива увага була приділена їх впливу на органолептичні показники.

У замороженому стані всі зразки мали однакові характеристики: незлиплі, нездеформовані пельмені круглої форми, краї тістової оболонки щільно склеєні, без виступів фаршу, під час струшування видавали характерний виразний звук.

Після термічної обробки пельмені з апельсиновими волокнами «Citri-Fi» мали гарний зовнішній вигляд і вигляд на розрізі, рівномірно перемішаний фарш, соковиту, ніжну консистенцію, приємний смак, запах, властиві доброякісній сировині, сіро-рожевий колір, оболонку з тіста не розірвану, не відсталу від фаршу.

Пельмені 3 клітковиною «ВіаФайбер» мали аналогічні показники кольору, смаку і запаху, проте консистенція була більш щільною та несоковитою.

Зразок із морквяною клітковиною «Нессе» мав добрі показники зовнішнього вигляду та вигляду на розрізі, смаку і запаху, однак спостерігалася незначна щільність та нерівномірність за кольором, що, ймовірно, пов'язано з нерівномірним розподілом клітковини.

Зразок із картопляною клітковиною «Роtех» мав сторонній присмак та фарш, який дуже сильно відійшов від тістової оболонки.

Контролю був притаманний характерний для доброякісної сировини запах, смак і колір, суха та занадто щільна консистенція.

Висновки та пропозиції. Результати проведених досліджень щодо вивчення впливу харчових добавок рослинного походження на функціонально-технологічні властивості заморожених м'ясних напівфабрикатів дозволили відзначити апельсинові харчові волокна «Citri-Fi». Вважаємо перспективним подальший напрям робіт з розробки нових рецептур заморожених м'ясних напівфабрикатів у тістовій оболонці із використанням у їх рецептурному складі харчових апельсинових волокон «Citri-Fi», що своєю чергою дасть можливість розширити асортимент високоякісної і конкурентоспроможної м'ясної продукції із заданими властивостями.

\section{СПИСОК ВИКОРИСТАНОЇ ЛІТЕРАТУРИ:}

1. Свистун Т.В., Туз К.В. Аналіз ринку заморожених напівфабрикатів України. Економіка харчової промисловості. 2017. № 2 (9). С. 19-23.

2. Полуфабрикаты высокой степени готовности: обзор рынка и организация бизнеса. Киев, 2018. URL: https://www.kreston-gcg.com (дата звернення: 29.09.2021). 
3. Лисицын А.Б., Иванкин А.Н., Вострикова Н.Л., Становова И.А. Изучение фракционного состава белков мяса в процессе длительного холодильного хранения. Все о мясе. 2014. № 2. С. 36-40.

4. Глушков О.А. Усовершенствование технологии производства быстрозамороженных мясных полуфабрикатов : дис. ... канд. тех. наук : 05.18.16. Одесса, 2010. $160 \mathrm{c}$.

5. Нечаев А.П., Кочеткова А.А., Зайцев А.Н. Пищевые добавки. Москва, 2002. $256 \mathrm{c}$.

6. Бакулин О., Марташов Д. Загустители и структурообразователи. Пищевая промышленность. 1999. № 11. С. 30-32.

7. Баль-Прилипко Л.В. Актуальні проблеми галузі : навчальний посібник. Київ, 2010. 374 с.

8. Баль-Прилипко Л.В., Леонова Б.І. Традиційні та сучасні принципи використання речовин природного походження для виробництва високоякісних м'ясних продуктів. Мясное дело. 2010. № 11. С. 32-35.

9. Лазенков С.А., Ревенко Е.Ю. Пищевые волокна Justfiber как натуральный функциональный ингредиент. Мясное дело. 2004. № 8. С. 18-19.

10. Коновалов К.Л. Растительные ингредиенты в производстве мясных продуктов. Пищеевая промышленность. 2006. № 4. С. 68-69.

11. Кватирка О. Клітковина: особливості використання харчових волокон у м’ясній промисловості. М'ясні технології світу. 2010. № 11. С. 28-32.

12. Димитрієвич Л.Р., Степанова Т.М., Маренкова Т.I. Харчові волокна в технології м’ясних продуктів. Мясное дело. 2011. № 4. С. 10-11.

13. Штонда О.А. Підвищення якості січених напівфабрикатів за рахунок використання харчових волокон. М'ясні технології світу. 2010. № 12. С. 48-50.

14. Желєва Т.С., Янчева М.О., Большакова В.А. Суміші «KrioMeat» у технологіях виробництва напівфабрикатів м'ясних посічених заморожених. Розвиток технічних наук: проблеми та рішення : матеріали міжнар. наук.-практ. конф., м. Брно, 27-28 квітня 2018 р. Чеська Республіка, Брно, 2018 р. С. 91-95.

15. Капрелянц Л.В., Іоргачова К.Г. Функціональні продукти : монографія. Одеса : Друк, 2003. 312 с.

16. Рогов И.А., Забашта А.Г., Казюлин Г.П. Технология мяса и мясных продуктов. Москва, 2009. 565 с.

17. Антипова Л.В., Глотова И.А., Рогов И.А. Методы исследования мяса и мясных продуктов : учебное пособие. Москва, 2004. 571 с.

\section{REFERENCES:}

1. Svystun, T.V., \& Tuz, K.V. (2017). Analiz rynku zamorozhenykh napivfabrykativ Ukrainy [Analysis of the Market of Frozen Semi-finished Products of Ukraine]. Ekonomika kharchovoi promyslovosti - Economics of the food industry, 2 (9), 19-23 [in Ukrainian].

2. Polufabrikaty vysokoj stepeni gotovnosti: obzor rynka i organizaciya biznesa [Highly prepared semi-finished products: market overview and business organization]. Retrieved from: https://www.kreston-gcg.com [in Ukrainian].

3. Lysytsyn, A.B., Yvankyn, A.N., Vostrykova, N.L., Stanovova, Y.A. (2014). Yzuchenye fraktsyonnoho sostava belkov miasa $\mathrm{v}$ protsesse dlytelnoho kholodylnoho khranenyia [The study of the fractional composition of proteins of meat in the process of long-term cold storage]. Vse o myase-All about meat, 2, 36-40 [in Russian].

4. Hlushkov, O.A. (2010). Usovershenstvovanie tekhnologii proizvodstva bystrozamorozhennyh myasnyh polufabrikatov [Improvement of the technology for the production of frozen meat semi-finished products]. Candidate's thesis. Odessa [in Ukrainian].

5. Nechayev, A.P., Kochetkova, A.A., Zaitsev, A.N. (2002). Pishchevyye dobavki [Nutritional supplements]. Moscow: Kolos [in Russian]. 
6. Bakulin, O., \& Martashov, D. (1999). Zagustiteli i strukturoobrazovateli. [Thickeners and structurants]. Pishchevaya promyshlennost - Food industry, 11, 30-32 [in Russian].

7. Bal-Prylypko, L.V. (2010). Aktualni problemy haluzi [Current problems of the industry]. Kyiv [in Ukrainian].

8. Bal-Prylypko, L.V, \& Leonova, B.I. (2010). Tradytsiini ta suchasni pryntsypy vykorystannia rechovyn pryrodnoho pokhodzhennia dlia vyrobnytstva vysokoiakisnykh miasnykh produktiv [Traditional and modern principles of the use of natural substances for the production of high quality meat products]. Miasnoe delo-Meat business, 11, 32-35 [in Ukrainian].

9. Lazenkov, S.A., \& Revenko, E.YU. (2004). Pishchevye volokna Justfiber kak natural'nyj funkcional'nyj ingredient [Dietary fiber Justfiber as a natural functional ingredient]. Myasnoe delo - Meat business, 8, 18-19 [in Ukrainian].

10. Konovalov, K.L. (2006). Rastitel'nye ingredienty v proizvodstve myasnyh produktov [Herbal ingredients in the production of meat products]. Pishchevaya promyshlennost - Food industry, 4, 68-69 [in Russian].

11. Kvatyrka, O. (2010). Klitkovyna: osoblyvosti vykorystannia kharchovykh volokon u miasnii promyslovosti [Klitkovina: the peculiarities of the pickling of grub fibers in meat industry]. Miasni tekhnolohii svitu - Meat technologies of world, 11, 28-32 [in Ukrainian].

12. Dymytriievych, L.R., Stepanova, T.M., Marenkova, T.I. (2011). Kharchovi volokna $\mathrm{v}$ tekhnolohii miasnykh produktiv [Food fibers in the technology of meat products]. Myasnoe delo - Meat business, 4, 10-11 [in Ukrainian].

13. Shtonda, O. A. (2010). Pidvyshchennia yakosti sichenykh napivfabrykativ za rakhunok vykorystannia kharchovykh volokon [Adjusting the quality of many products due for the use of grub fibers]. Miasni tekhnolohii svitu-Meat technologies of world, 12, 48-50 [in Ukrainian].

14. Zhelieva, T.S., Yancheva, M.O., Bolshakova, V.A. (2018). Sumishi "KrioMeat" $\mathrm{u}$ tekhnolohiiakh vyrobnytstva napivfabrykativ miasnykh posichenykh zamorozhenykh [The sums of "KrioMeat" in technologies of production of meats semi-finished products in many frozen]. Materialy Mizhnarodnoyi naukovo-praktychnoyi konferentsiiyi "Rozvytok tekhnichnykh nauk: problemy ta rishennia" - Proceedings of the International Scientific and Practical Conference "Development of technical sciences: problems and solutions". Pp. 91-95. Brno.

15. Kapreliants, L.V., \& Iorhachova, K.H. (2003). Funktsionalni produkty [Functional products]. Odesa: Druk [in Ukrainian].

16. Rohov, I.A., Zabashta, A.G, Kaziulyn, H.P. (2009). Tekhnolohyia miasa y miasnykh produktov [Technology of meat and meat products]. Moscow: KolosS [in Russian].

17. Antypova, L.V., Hlotova, I.A., Rohov, I.A. (2004). Metody issledovanyia miasa $\mathrm{y}$ miasnykh produktov [Methods of research of meat and meat products]. Moscow: KolosS [in Russian]. 